\title{
CLASSIFICATION SCHEME FOR SURFACE TEXTURES OF GOLD NUGGETS FROM FINNISH LAPLAND
}

\author{
KARI A. KINNUNEN
}

KINNUNEN, KARI A., 1996: Classification scheme for surface textures of gold nuggets from Finnish Lapland. Bull. Geol. Soc. Finland 68, Part 2, $18-33$.

A study was made of the surface textures of about 100 gold nuggets (diameter 2-56 $\mathrm{mm}$ ) sluiced and panned in the Lemmenjoki, Ivalojoki and Tankavaara areas of northern Finland. The placer gold localities all represent a recently glaciated environment. Surface textures were identified from acetate peels using optical microscopy, image analysis and experimental wear tests. Classification of the surface markings into primary (origin in bedrock), secondary (origin in sediments) and anthropogenic (man-made) groups resulted in a scheme including 6 subgroups and 16 types. The diagnostic features of each surface marking type are described and defined. The relative extents of surface marking types were measured as areal percentages with a point counting procedure, facilitating the comparison of individual nuggets. Applications of the technique range from fingerprinting of individual valuable nuggets in jewellery trade to mineralogical reconnaissance studies as a guide for gold transport.

Key words: gold ores, placers, nuggets, surface textures, classification, genesis, Lapland, Finland.

Kari A. Kinnunen: Geological Survey of Finland, FIN-02150 Espoo, Finland. E-mail: kari.kinnunen@gsf.fi

\section{INTRODUCTION}

The physical and chemical properties of placer gold are of inherent value as exploration indicators (Antweiler and Campbell 1977, Knight 1992, Leake et al. 1993, Loen 1995). In combination with chemical data and petrophysical measurements the study of surface textures forms the basis of a nondestructive analytical procedure developed at the Geological Survey of Finland for the characterization of large gold nuggets (Kinnunen et al. 1995, 1996, 1997). The determination of chemical composition and petrophysical properties can be readily performed using established laboratory methods with modified preparation techniques 
but the analysis of surface features has required the development of several new methods, as explained in this article.

In comparison with some other detrital minerals, such as quartz, the surface markings of gold nuggets have received little attention. In principle, the surface textures of placer gold can be interpreted using procedures similar to those applied to quartz and heavy mineral grains (cf. Krinsley and Doornkamp 1973, Rahmani 1973, Culver et al. 1983, Mahaney 1995). For example, Culver et al. (1983) identified 32 surface texture types from sand-size quartz grains. Surface texture studies of larger clasts, namely pebbles and boulders (occurring in the same size range as the large gold nuggets), have so far revealed only three surface texture types: 1 . striations, 2 . percussion and chatter marks and 3. chink-facets (Gale and Hoare 1991, p. 106-109).

DiLabio (1991) has devised a classification scheme based on scanning electron microscopy (SEM) of small $(0.1-0.2 \mathrm{~mm})$ gold grains specific to glaciated terrain in Canada. His shape classes for detrital gold are pristine (unmodified), modified and reshaped. DiLabio classified his pristine class into seven shape categories: block, rod, wire, leaf, crystal, star and globule or bleb. The modified and reshaped class includes all shapes modified and reshaped to varying degrees, the ultimate end shapes being the typical discoid placer flake and nugget. DiLabio (1991) listed 12 surface texture types: smooth surfaces, angular edges, grain moulds clearly visible, thin edges not curled, some striae, leaf edges and wires bent, blunted and clubbed edges, grain moulds preserved where protected, moderately striated, felty texture, porous or spongy, and rarely striated.

Mahaney (1991) and Herail (1991) used SEM to study the surface textures of gold grains from glacial deposits (tills) in Peru and Bolivia. According to Herail (1991) "in glacial environments the gold particles are characterized by wide, deep striae, crushing marks and refolded or typically rolled edges." Mahaney (1991) identified 12 microtexture types: cracking, thinning, folding, pinching, solution etching, patina, impact craters, percussion cracks, corrosion pits, grooves, preweathering and adhering particles.

In Finland, Huhta (1993) classified the gold grains washed from tills in the Ilomantsi area into angular, slightly rounded and distinctly rounded shape classes. His classification corresponds to that of DiLabio (1991). The classification of gold grains in Ilomantsi till by Nikkarinen (1991) combined the primary shapes with secondary modifications: 1 . flat grains, 2 . euhedral and 3. irregularly shaped grains. Huhta (1993) and Nikkarinen (1991) did not document the surface textures.

Simulations of gold nugget abrasion are rare. Yeend $(1975,1991)$ performed experimental studies on the abrasion of detrital gold in a tumbler using mixtures of sand, cobbles and water and tumbling time. The abraded gold grains were then observed with SEM. When using cobbles, sand and water the gold nuggets acquired very irregular, pitted surfaces. It is noteworthy that only the nuggets tumbled with cobbles and water received abundant gouge and scratch marks on their surfaces in addition to irregularities and pitting. The combination of cobbles, sand and water effectively simulates the common bedload of gold-bearing rivers. It was found that the surfaces of gold nuggets tumbled with dry sand were smooth, with few pits and no scratches; the dry sand simulated eolian action.

In this paper the surface markings on gold nuggets from Finnish Lapland are described and classified into groups reflecting their genesis. Possible mechanisms of formation are examined based on simple mechanical tests.

\section{MATERIAL}

About 100 gold grains and nuggets $(2-56 \mathrm{~mm}$ ) were studied, of which about 40 were further examined with the new acetate peel method (Kinnunen 1995a). The samples all originated from three alluvial gold fields (river sediments) in northern Finland: Lemmenjoki (Miessijoki, 
Puskuoja, Jäkälä-Äytsi), Ivalojoki (Hangasoja and Sotajoki) and Tankavaara (Fig. 1). These gold fields occur within poorly sorted sediments that can be interpreted as late-glacial melt-water channels (glaciofluvial placers) in the Lemmenjoki and Ivalojoki areas, and as gold-bearing tills at Tankavaara (see Saarnisto and Tamminen 1987). Their total gold content is estimated as about 2 tons (Puustinen 1991). These placer gold occurrences overlie
Precambrian granulite bedrock near the northern margin of the region in which the preglacial weathered regolith has been preserved (Hirvas 1991). According to Ward et al. (1989) metamorphic inversion beneath the granulites may have dehydrated the underlying greenstones, leading to Au-rich retrogressive shear zones in the granulite bedrock. Quartz-carbonate veins along these shear zones could have been the source for the placer gold.

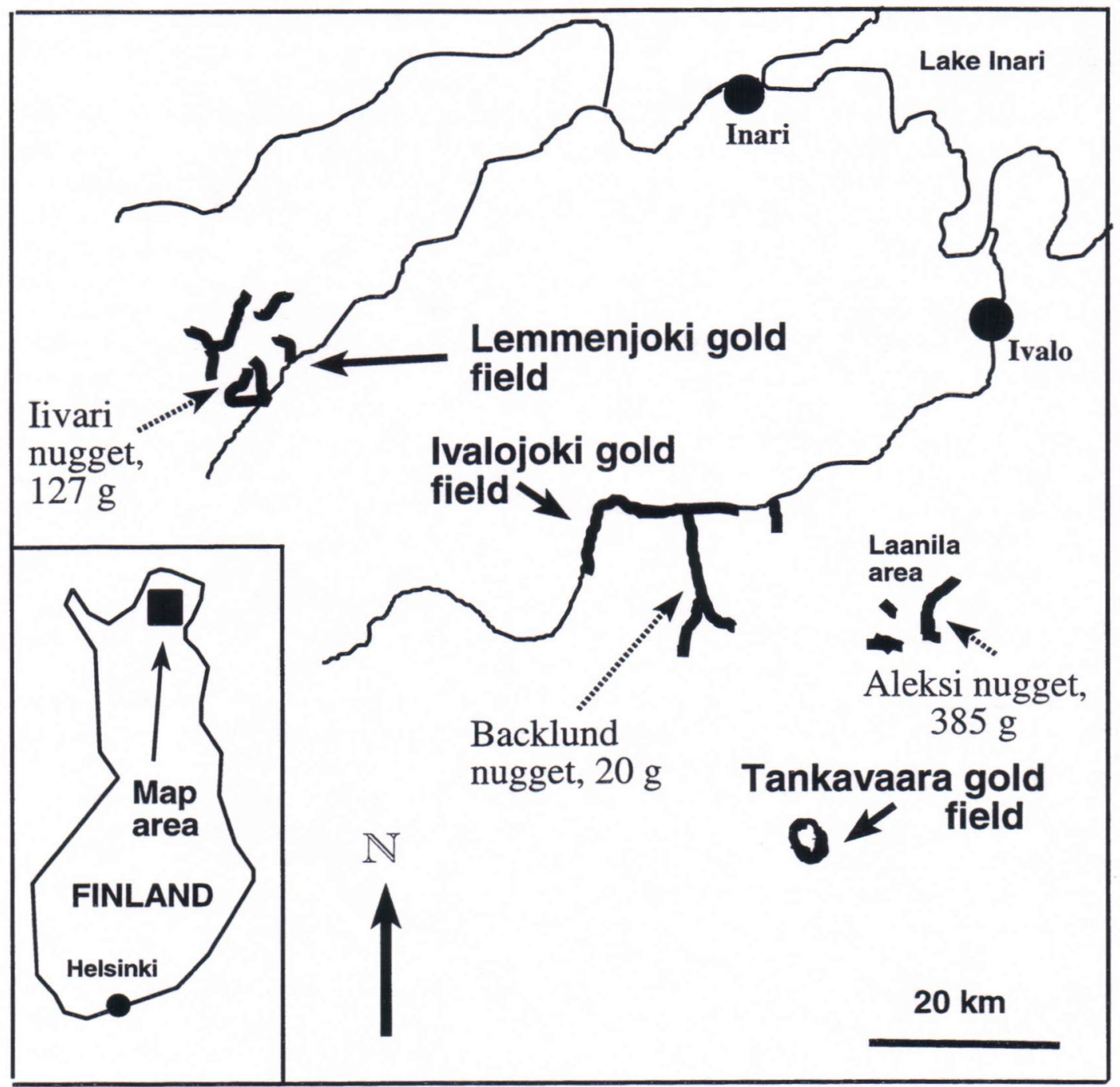

Figure 1. Location of gold placer areas in Finnish Lapland. The placers are depicted as thickened lines. The Laanila area is here considered as part of the Ivalojoki gold area. 
The largest nugget studied was Aleksi (385 g, $57 \times 52 \times 28 \mathrm{~mm}$ ), which was recovered in 1910 from Hangasoja near Laanila. The other large nuggets studied were livari (127 g, 36 x 31 x $28 \mathrm{~mm}$ ), panned in 1995 at Puskuoja, in the Lemmenjoki area, and Backlund (20.14 g, $25 \mathrm{x}$ $20 \times 6 \mathrm{~mm}$ ) from Sotajoki in the Ivalojoki area; the Backlund nugget was found as long ago as the 1880 's. The physical and chemical properties and shapes of these nuggets have been described by Kinnunen et al. $(1995,1996,1997)$. The smaller placer gold grains studied originated from the Lemmenjoki and Tankavaara fields.

\section{METHODS}

Study procedures are outlined in the chart shown in Fig. 2. The areas chosen for more detailed study were replicated on acetate sheet. The surface of the nugget was coated with acetone before having the acetate sheet placed over it. After drying the sheet was peeled off and inserted between glass slides and studied with transmitted light microscopy. The surface textures of gold nuggets were identified and classified visually from the peels using an optical microscope at low magnifications (10-100x) under Rheinberg illumination and shadowing (Kinnunen 1995a). Rheinberg illumination is an optical staining method employing multi-color filters. The shadowing was accomplished with sector diaphragms.

These low magnifications are effective for large gold nuggets because the smallest surface features had usually been obscured or obliterated by polishing (burnishing) resulting from human handling. Only those nuggets preserved intact after their discovery (usually the smallest nuggets) benefit from the use of higher magnifications. Surface texture abundances were measured as areal percentages with standard point counting procedures. The texture dimensions were measured by using a microscope eyepiece equipped with a screw micrometer. The mean sizes of the surface markings were determined from digitized photomicrographs on a micro computer using the UTHSCSA Image

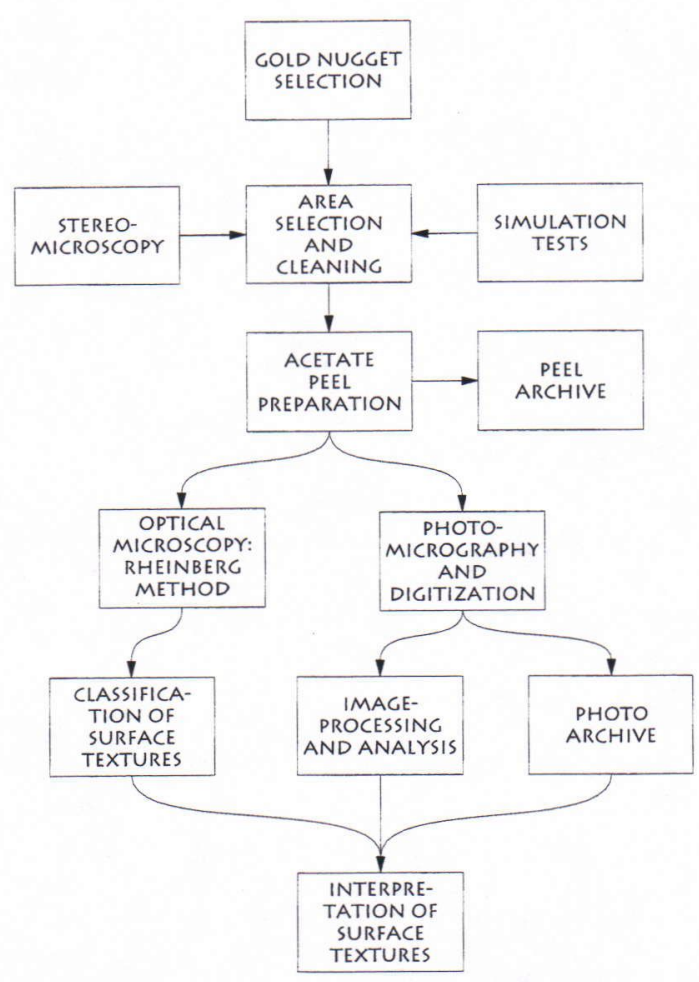

Figure 2. Flow chart showing the laboratory procedures developed for the micromorphological study of large gold nuggets.

Tool program (Kinnunen 1995b, Kinnunen et al. 1997).

Simple mechanical tests were made to simulate the formation of the markings. Edges of mineral grains were manually pressed against the gold surface. These simulated slow/static contacts, moving contacts and rapid impact-like contacts. The test piece was a plane-polished natural gold nugget. The variables were: (1) the pressure applied to the grain, (2) changing direction of movement from vertical to horizontal, and (3) point type: blunt/sharp edge, soft/hard mineral (calcite/quartz, feldspar). The tests were performed by manual rubbing and scraping as well as tumbling in a plastic container. Acetate peel prints were prepared from each test, after which the surface was repolished and the test was repeated several times. 


\section{CLASSIFICATION OF SURFACE MARKINGS}

A dense coverage of different types of surface markings was observed on gold nuggets from Finnish Lapland (Fig. 3). The size distribution of markings remained remarkably uniform for nuggets of increasing size up to $25 \mathrm{~mm}$ (Fig. 4). The surface markings were classified into three genetic groups: primary (inherited from bedrock), secondary (formed in sediment or soil) and anthropogenic (resulting from human handling) (Fig. 5). Respective subgroups and types are described and interpreted below together with the results of mechanical tests.

\section{Primary features}

The surfaces formed on gold crystals and grains within the bedrock carry primary surface features. In the classification they are divided into crystallization and deformation related subgroups (Fig. 5). The crystallization marks include primary cavities, microlaminations and growth hillocks; the deformation marks include striated surfaces and filaments (Fig. 5).

In bedrock occurrences the grain size, morphology and chemical composition of primary gold crystals vary in accordance with the lithostatic depth at which the gold has crystallized (Tarbayev 1991). At deep levels simple octahedra and cube-octahedra prevail, while at intermediate depths rhombic dodecahedrons are typical, and under high-level conditions more complicated lamellar and dendritic habits are characteristic (Petrovskaya 1971). Supergene gold crystals with over 990 fineness ( $\mathrm{Au} / \mathrm{Au}+\mathrm{Ag}$ multiplied by 1000 ), found in the kaolinite-rich weathering profile at Hannan South, Western Australia, are microscopic (diameter to $50 \mu \mathrm{m}$ ) plane-faced polyhedra, notably octahedra and octahedral

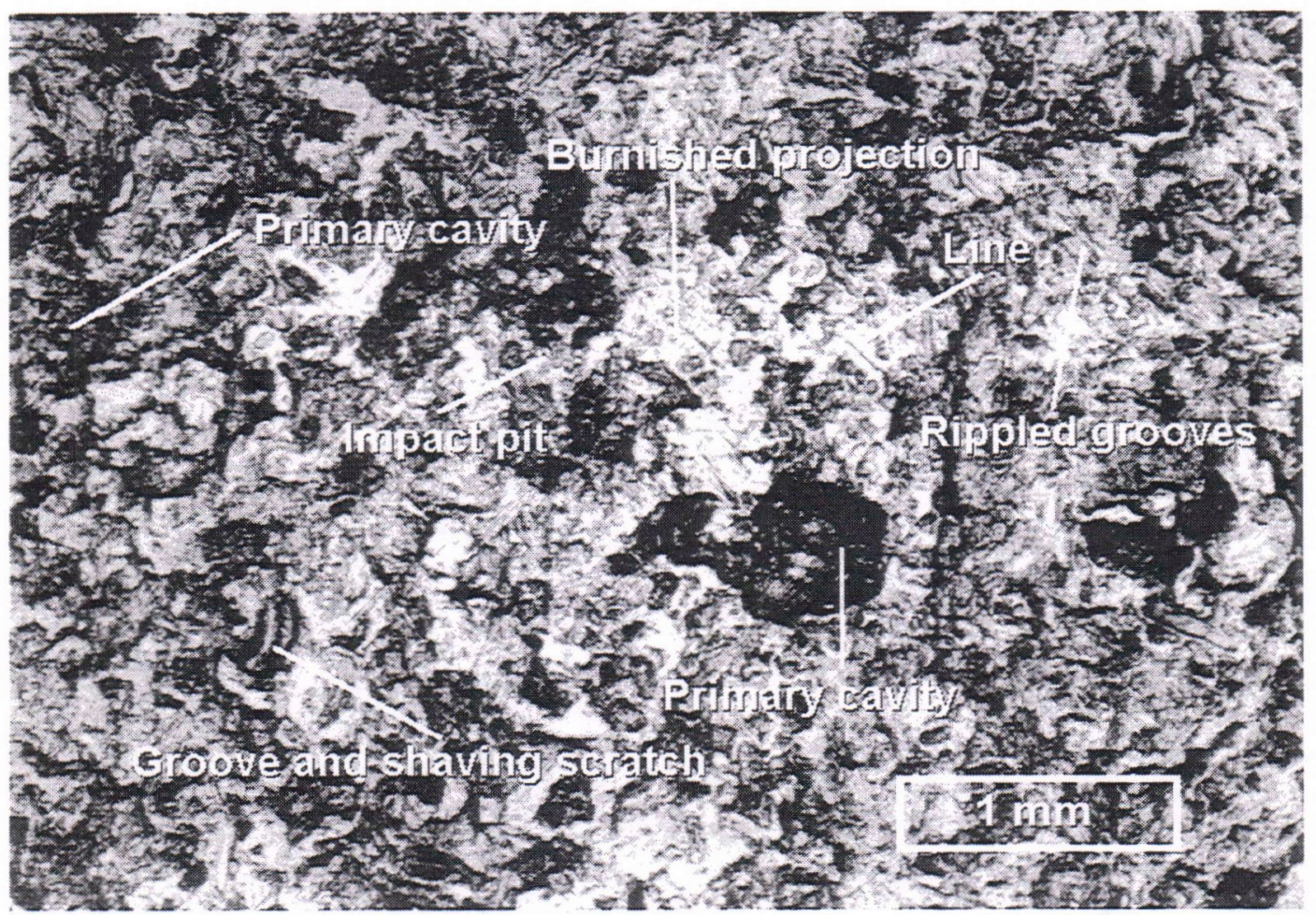

Figure 3. Digitized photomicrograph showing the most common surface marking types on the Aleksi gold nugget from Hangasoja, Laanila area, with the Ivalojoki gold field. The photomicrograph has been taken from an acetate peel. 


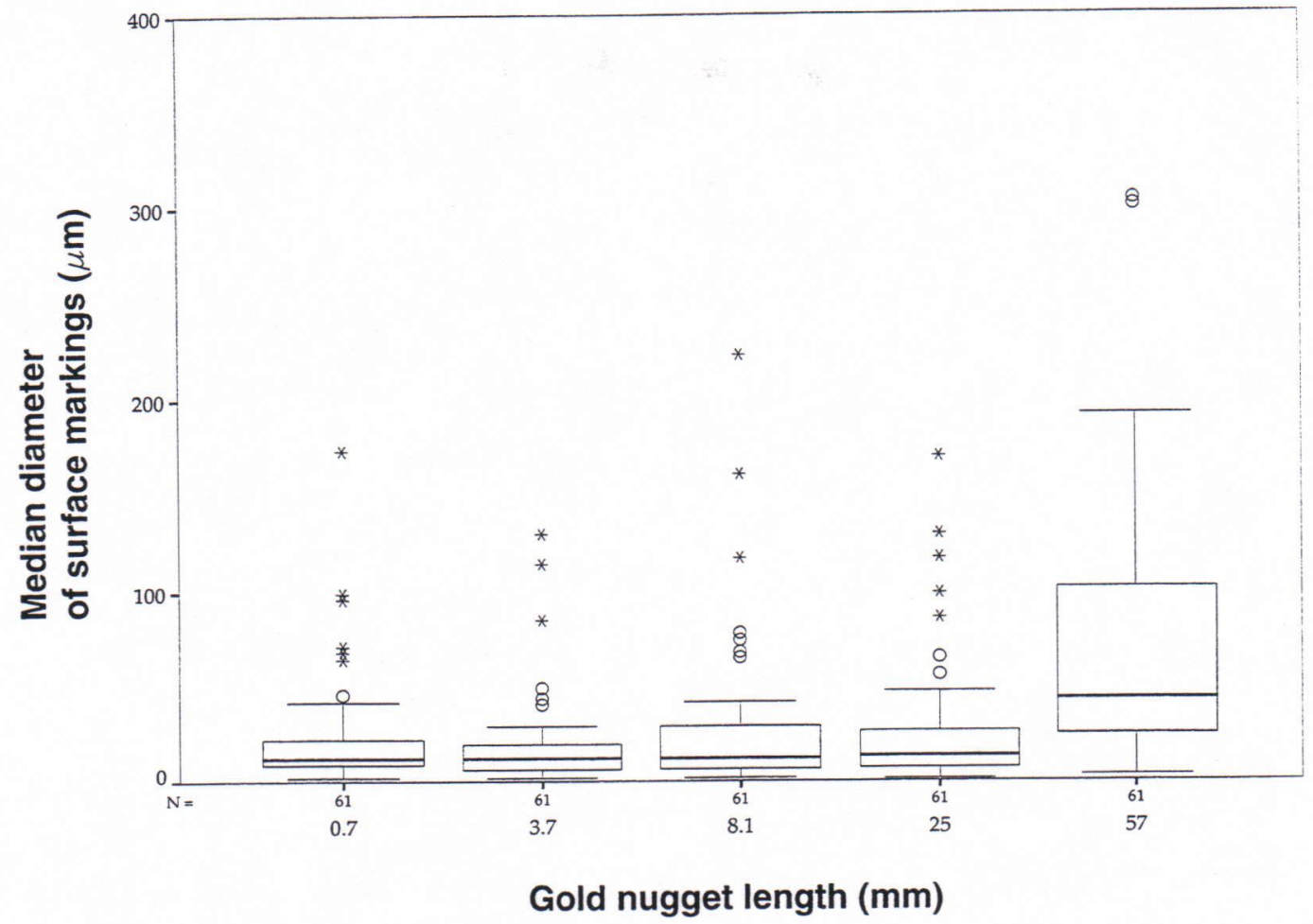

Figure 4. Box plot diagram of the mean, range, standard deviation and outliers for size measurements (median diameter) of the surface markings on gold nuggets of differing size from Finnish Lapland.

plates (Lawrance and Griffin 1994). Such crystal faces are commonly etched (trigons) and show microlaminations (Lawrance and Griffin 1994).

The surface textures typically observed on bedrock gold crystals are step-like and trigonal patterns (Petrovskaya 1971). According to Petrovskaya (1971) the steps are coarse (up to $0.1 \mathrm{~mm}$ ) in deep and intermediate ore types and smooth (from 100 to $0.1 \mu \mathrm{m}$ ) in shallow ones. Other primary surface features formed either when the gold particle crystallized or during subsequent bedrock deformation. The crystal faces of gold grown in open (fluidfilled) cavities may reveal microlaminations, growth hillocks, etch pits (trigons), and facets. Such primary textures, microlaminations and growth hillocks in the classification (Fig. 5), are easily abraded and destroyed during sedimentological processes.

Most of the crystallization textures described above are too delicate to survive erosional proc- esses and only the primary cavities of the crystallization related subgroup are common on the nuggets from Finnish Lapland.

Primary cavities (Figs. 5 and 6) are mouldlike forms and contact surfaces, created by adjacent and intergrown mineral grains. They are typical of Finnish nuggets, the most common being surfaces imprinted on gold when it crystallized within fracture networks in vein quartz (as on mixed gold/quartz nuggets) or in contact with carbonate crystals.

Usually the primary cavities show straight edges and simple geometric outlines with the most common form being pseudotriangular; diameters may attain $10 \mathrm{~mm}$ in the largest nuggets. The largest cavities can be considered to correspond to the grain size of the rock. Primary cavities lack gold rims (Fig. 6), which is a diagnostic feature enabling them to be to distinguished from the secondary rimmed pits. 


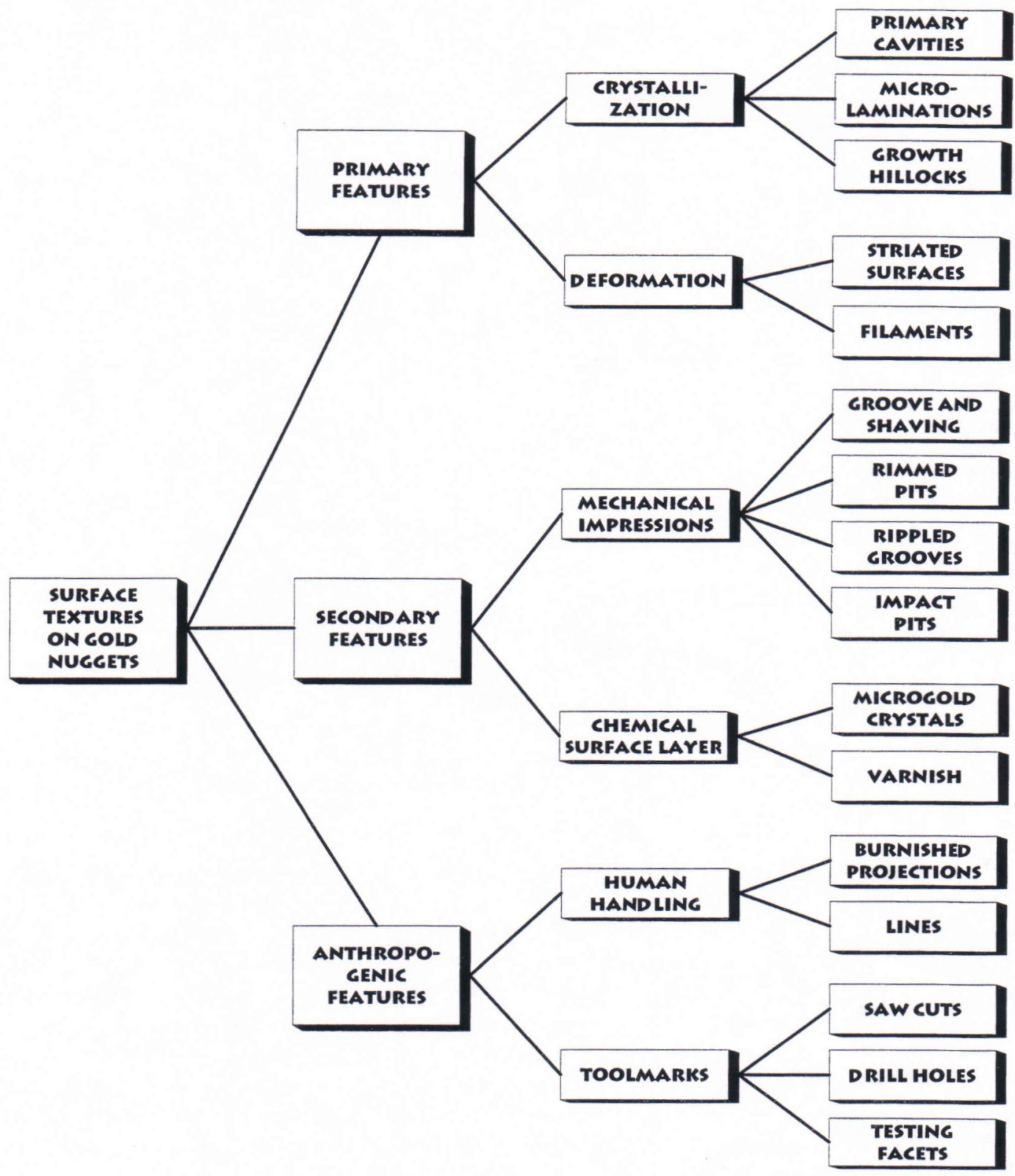

Figure 5. Classification scheme for surface textures developed for gold nuggets from glaciated environments.

The primary cavities of uncleaned specimens commonly contained loosely adhering detrital material. This material was analyzed by grain counting (see Kinnunen et al. 1996) but usually only gives information concerning the modern sedimentary environment from which the nugget was excavated.

The deformation related primary subgroup of primary features includes tectonic striated surfaces (Fig. 5); these are usually parallel and can thus be distinguished from glacigenic 

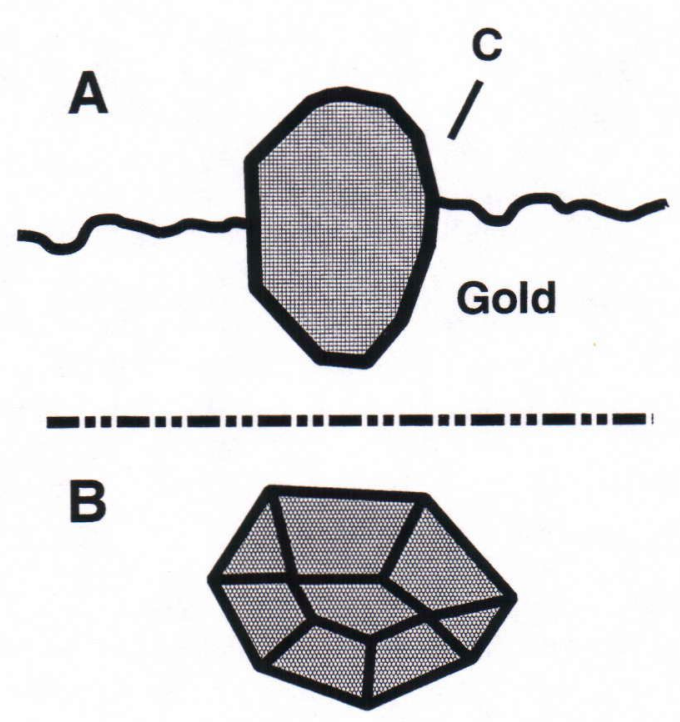

\section{$1 \mathrm{~mm}$}

Figure 6. Schematic drawing of a primary cavity in profile $(A)$ and from above $(B)$. The negative form, mould, of a weathered or loosened crystal $(C)$ is characteristic of this surface marking type. Note the $a b-$ sence of a rim, which serves to distinguish it from the otherwise similar rimmed pit type.

scratches that typically have random orientations. Rare, pulled filaments (Fig. 5) are also formed during these processes. Tectonic deformation features have not been observed in nuggets from Finnish Lapland.

\section{Secondary features}

Secondary surface features have formed on the gold grains in sediments and soils. They are here classified into mechanical and chemical subgroups. The mechanical subgroup includes groove and shaving scratches, rimmed pits, rippled grooves and impact pits and the chemical subgroup microgold crystals and varnish (Fig. 5). The mechanical markings represent adhesive and abrasive types of wear characteristic of metals (cf. Sarkar 1976). Ductile and fatigue fractures, common in metals (see McCall and French 1977), were not observed on the Finnish nuggets. The fracture-like features common on some Finnish nuggets were interpreted as contact surfaces formed during folding (Kinnunen et al. 1996). The diagnostic features of the mechanical markings are described first.

Groove and shaving scratches (Fig. 7) resemble the macroscopic nail-head striae seen on glaciated rock surfaces (see Prest 1983). They usually record shaving on the distal end of the scratch. The length of the markings ranges from several millimeters down to a few micrometers. The shaving is formed from the gold gouged from the bottom of the scratch in front of the protruding mineral edge. The floors of the grooves are lined with ridges oriented longitudinally, while the largest marks are also rimmed on the bottom. Many marks exhibit deformation lamellae surrounding their leeward ends. These deformation lamellae can be interpreted as slip planes of gold and while they commonly formed during the simulation tests (performed on plane gold surfaces), they were not observed on natural nugget surfaces, due to the effects of erosion.

Simulation tests showed that the groove and shaving marks are produced by scratching of the gold surface by mineral and rock edges. Very little force is needed for their formation. The hardness of the protruding material must exceed the gold hardness value - otherwise polishing is induced on the surface. Scratching by exerting strong pressure and with hard materials (sharp corners of quartz fragments and granitoid pebbles) produced scratches in the form of groove/shaving tracks. The pressure applied corresponded to variations in length/breadth ratios; high pressures caused low L/B-ratios. Scratching with soft minerals (calcite) - still slightly exceeding the hardness of gold produced nail-head like scratches. The shaving part was not so pronounced as with harder materials because greater pressure blunts the edge of the soft point. Scratching tests were also made with clean ice but no scratches were 

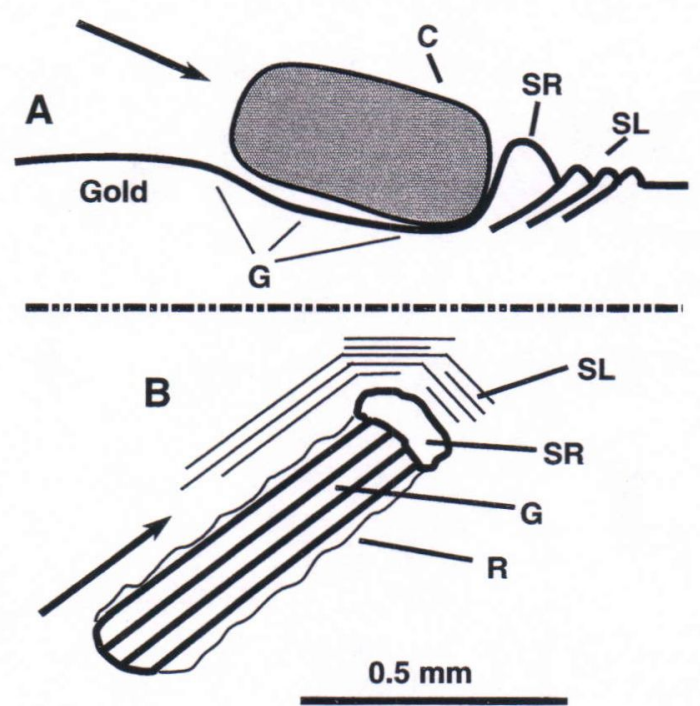

Figure 7. Schematic drawing of a groove and shaving scratch in profile $(A)$ and from above $(B)$. The protruding clast $(C)$ has ploughed in the arrowed direction. This surface marking type consists of a groove $(G)$, rim (R), shaving rim (SR) and slip planes (SL). The dimensions of the slip planes are exaggerated in the profile.

produced, nor was any evidence for polishing seen. This is because the surface layer of ice either melted due to friction or (in other tests) froze tightly to the nugget surface.

Rimmed pits (Fig. 8) are produced when vertical pressure is applied by indenting a hard mineral edge (quartz, feldspar etc.) without horizontal movement along the gold nugget surface. Their bottoms are molded according the surface topography of the protruding edge. The bottom is micropitted (in the case of calcite and other mineral soft protruding corners) and a rim is formed by a gold layer. The markings are surrounded by a wide area of deformation lamellae (in simulation gold surfaces). These lamellae are considered to originate as slip planes in the gold lattice. On natural gold nuggets these have almost invariably been obscured by erosional effects. If the pressure is slightly oblique, the pit is deformed, the bottom is slightly scratched, and the gold rim is present only on one side. The markings are transformed into scratches when the horizontal component becomes more dominant. The diameters of these marks vary from a few millimeters down to several micrometers.

The rimmed pits and the deformation lamellae surrounding them (Fig. 8) are analogous to the micro-indentation pits induced on metals and observed with interferometric methods by Tolansky (1960, p. 183-218). His results show that surface flow is observed as slip and twinning planes leading to microstepped hillocks surrounding the indenter pits.

Rippled grooves (Fig. 9) resemble microscopic ripples or waves. They are composed of a network of overlapping small and shallow groove and shaving scratches sharing the same linear orientation. The combined thickness of the deformed layer composing them varies from 6 up to 20 microns, while the area covered by a network of rippled grooves may attain several millimeters in length. Tumbling for 3 minutes in a small plastic container with gravel, sand and

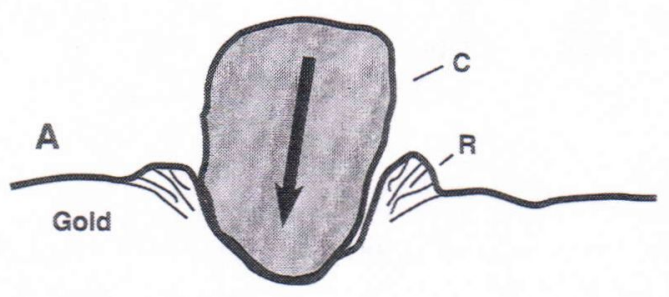

B

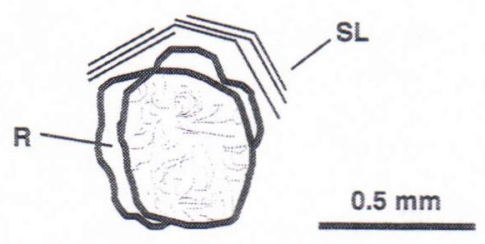

Figure 8. Schematic drawing of a rimmed pit in profile $(A)$ and from above $(B)$. The vertically protruding clast has imprinted part of its morphology and flow lines indicating the direction of movement against the pit bottom. This surface marking type consists of pit, rim $(R)$ and slip planes $(S L)$. 
water ( $2 / 3$ fill) and shaking about 2 times per second caused the formation of closely spaced pits and a network of rippled grooves forming a dense coverage of markings. They may be analogous to the impact scars described from detrital quartz grains (see Krinsley and Doornkamp 1973).

Impact pits (Fig. 10) are sometimes seen on the bottoms of relatively smooth secondary scratches. Their bottoms were commonly smooth although larger markings showed pitted or striated bottoms as well. They were also commonly only slightly rimmed. Shaking in a plastic container with dry sand produced, small, typically very regular spherical pits having diameters of only a few micrometers. When compared to Tolanskys (1960, p. 220) micro-interferometric tests, it can be inferred that the impact pits exhibit evidence for shallowing by recovery.

Chemical features (Fig. 5) are formed when the surface layer is leached leading to microgold formation or when iron and aluminium rich surface coatings are deposited on its surface as a varnish. The chemical composition of the varnish layer resembles that of lateritic material (see
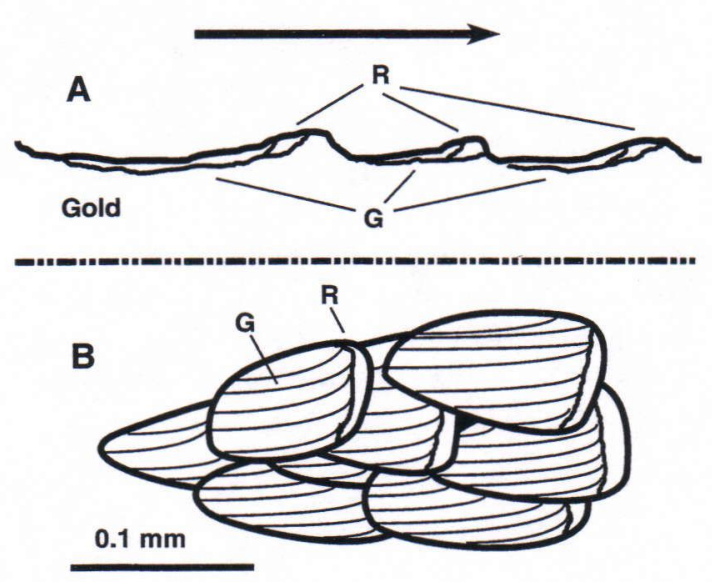

Figure 9. Schematic drawing of rippled grooves in profile (A) and from above (B). This surface marking type consists of a network of grooves $(G)$ and rims $(R)$ trending in the same direction (arrow).
Saarnisto and Tamminen 1987) and podzolic cutans.

A microgold layer was present in most nuggets at the base of the primary and secondary features: rimmed pits, primary cavities and some scratches and grooves. In contrast, anthropogenic surfaces lacked these microgold crystals and were highly reflective and shiny, this being their most distinguishing feature. The diameter of these microgold crystals ranged from 1 to $3 \mu \mathrm{m}$.

Most studies on placer gold refer to the presence of spongy-textured microgold on the surface of placer gold. This rim is porous and composed of high-purity gold (Craig 1990). According to Groen et al. (1990) the rim (from to $60 \mu \mathrm{m}$ in thickness) is composed of microgold crystals and caused by self-electrorefining of placer gold and electrum from its silver and copper contents in sediments.

The presence of a microgold layer is a critical identification feature, which separates the secondary surface markings from the anthropogenic group described in the following section. Anthropogenic markings are not covered with microgold crystals.
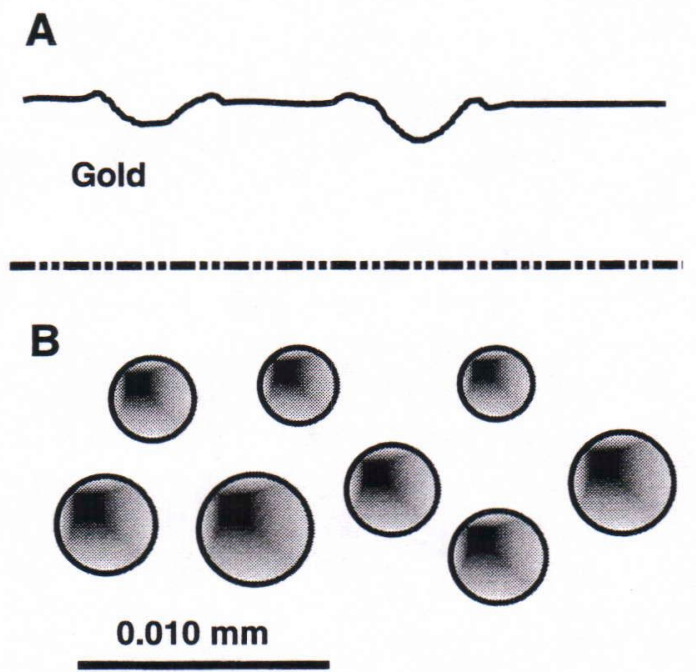

Figure 10. Schematic drawing of impact pits in profile (A) and from above (B). The characteristic feature of this surface marking type is the smooth bottom. 


\section{Anthropogenic features}

Anthropogenic surface features (Fig. 5) can be classified into toolmarks and marks caused by the human handling of the nuggets. Large, historical gold nuggets commonly reveal different toolmarks formed variously during excavation, sluicing and panning operations, handling in the laboratory or by jewellers when the gold content was being analyzed with classical wet chemical methods (see Mercer 1992). Such features include saw cuts, drill holes and testing facets (Fig. 5). The testing facets are formed when the inspected gold piece is scraped against a testing stone (lydian stone) usually cut from a fine-grained, blackish rock (chert or basalt). The testing facet is a planar surface crossed by parallel coarse scrathes.

Burnished projections (Fig. 11) are produced by moderate rubbing against soft materials (paper, cloth, leather and finger tips) leading to polishing by plastic flow of the projecting parts of the surface. Such polished areas are common on large historical nuggets handled by many people. Touching with fingers easily polishes the microcorners of nuggets. The burnished projec-
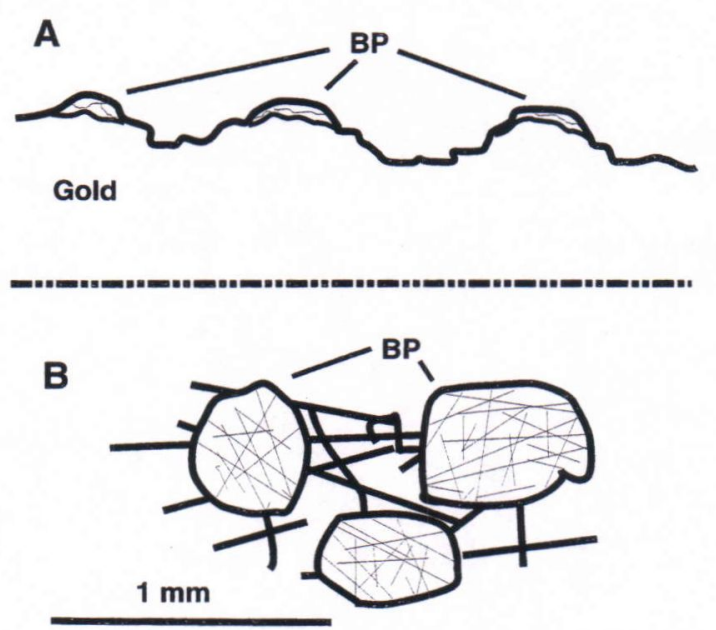

Figure 11. Schematic drawing of burnished projections $(B P)$ in profile $(A)$ and from above $(B)$. These polished microhills are typically crossed by faint straight lines. tions smooth the most intricate surface textural patterns present only in unhandled placer gold grains. The burnished projections are commonly crossed by straight microscopic lines (Fig. 11). According to the simulation tests these lines are formed by dust present at the contact.

Rabinowicz (1968) interprets burnishing of a metal surface as polishing without the use of abrasives. Burnishing is accomplished by rubbing the surface with hard or soft material at low pressure (load). According to Rabinowicz (1968) the load is critical, because higher load leads to roughening of the surface. On a polished surface the diameter of the surface markings stays below the wavelength of light $(0.4-0.7 \mu \mathrm{m})$.

\section{SURFACE TEXTURE ANALYSES}

The surface textures of gold nuggets can be numerically expressed as areal percentages occupied by each surface marking type, as determined by point counting. The percentage value of the anthropogenic markings increases with the amount of human handling. Anthropogenic marks are usually formed on secondary markings, while the number of primary markings (deep and larger) remains unchanged. As an example the analyses of the Aleksi, Iivari and Backlund nuggets are given in Figure 12. They show that burnished projections and rimmed pits are the most common surface marking types on the large gold nuggets from Finnish Lapland. The historically oldest nugget known from Lapland (Backlund, recovered in 1880 's), is half covered with burnished projections, indicating prolonged human handling. The shallowest markings (rippled grooves) have already been obliterated from the Backlund nugget during the course of human handling.

\section{DISCUSSION AND CONCLUSIONS}

The well-preserved genetically classifiable surface markings on Finnish nuggets show that detrital gold nuggets are suitable for micromorphological studies. This can be ascribed to the 
mechanical properties of gold, it being a soft (Vickers hardness number 30-58 with $10 \mathrm{~g}$ load), very malleable and ductile metal (Anthony et al. 1990). These properties arise from its face-centered cubic structure, which allow slip plane deformation on 12 directions parallel to octahedral planes and cubeface diagonals (Hertzberg 1976). Mechanical interactions are thus readily recorded as markings on the surface of gold. Because of the very high resistance of gold to chemical weathering, surface textures are eliminated only by mechanical reworking. Original surface textures have even been preserved on nuggets separated from fossil Precambrian gold placers of Witwatersrand in South Africa (Hallbauer and Utter 1977).

Studies of deformation induced on metals and minerals in micro-hardness determination (see Bowie and Simpson 1977) are pertinent for the interpretation of the surface textures on gold nuggets. Tolansky (1960) made detailed multiple-beam interferometric surface microtopographical observations on deformation mechanisms in metals when penetrated by rounded, conical and pyramidal indenters. Tolansky observed that indenter pits are commonly surrounded by surface flow structures (slip planes) although the smallest indenter pits are characterized by recovery features (shallowing). This is in agreement with observations from Finnish nuggets in which rim formation of slip plane type is commonly seen around larger mechanical markings (rimmed pis and groove and shaving scratches). This shows that the absence of rims in primary cavities is diagnostic of mechanism of formation and demonstrates their bedrock origin.

Most large gold nuggets from Finnish Lapland are devoid of exposed mineral inclusions but their former presence is

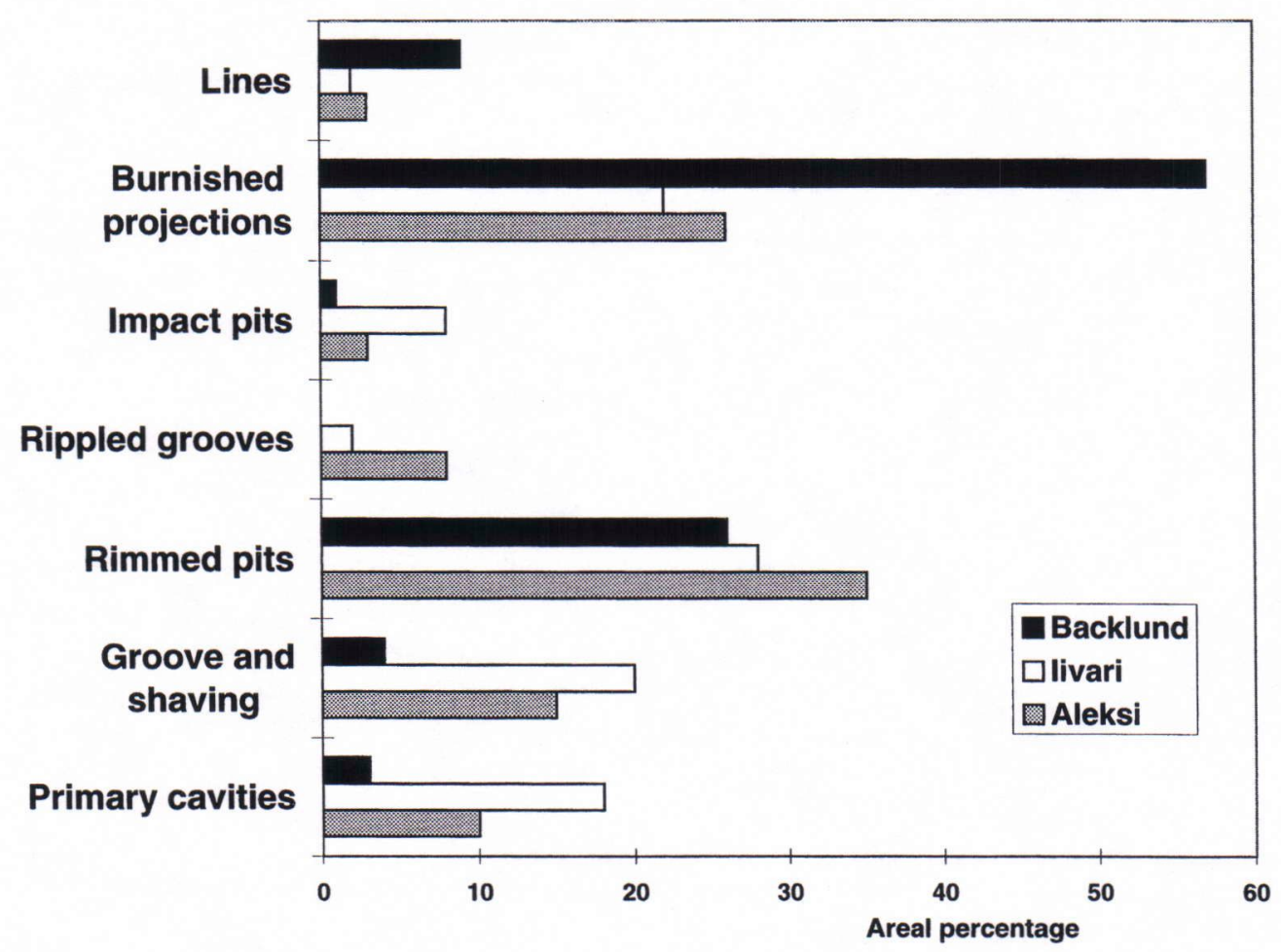

Figure 12. Surface texture composition of three large gold nuggets from Finnish Lapland (see Fig. 1): Aleksi $385 \mathrm{~g}$ (Hangasoja), Iivari $127 \mathrm{~g}$ (Puskuoja) and Backlnd $20 \mathrm{~g}$ (Sotajoki). 
commonly indicated by the retention of crystal face impressions as primary cavities on nugget surfaces. These primary cavities provide information on the shape, size and amount of gangue minerals in the gold-rich source rocks. With respect to gangue minerals the gold nuggets vary from almost pure nuggets (this study) to very impure grains (mixed nuggets) with 98 vol.\% of gangue (Kinnunen 1991). The imprint types also show that the gold nuggets are derived from coarse-grained rocks (up to $10 \mathrm{~mm}$ in grain size) and most probably from veins. The grain size and textures of the gangue material are characteristic of gold-bearing veins in many gold camps (cf. Dowling and Morrison 1989,
Sustavov 1985), and therefore have potential as guides to prospecting in Finnish Lapland as well. The undeformed, regular shape of the primary cavities together with the absence of fracture surfaces and tectonic striae on the nuggets all suggest that the auriferous veins were not subject to further tectonic deformation following gold precipitation and crystallization.

The main properties of placer gold from Finnish Lapland are summarized in Table 1, which shows that observations of surface textures and morphology are significant for interpretation (see Kinnunen et al. 1997). The only supergene component of the Finnish nuggets is the microgold layer present on

Table 1. Summary of the characteristic properties of placer gold in the Lemmenjoki, Ivalojoki and Tankavaara areas in northern Finland (see Fig. 1).

\begin{tabular}{|c|c|c|}
\hline Property & Characteristics & References \\
\hline Size (diameter) & $\begin{array}{l}\text { Common: } 0.10-0.25 \mathrm{~mm} \\
\text { Rare: up to } 6 \mathrm{~cm}\end{array}$ & $\begin{array}{l}\text { V. Saarinen (several unpublished reports in } \\
\text { GSF archives) }\end{array}$ \\
\hline Morphology & $\begin{array}{l}\text { Common: all modified shapes } \\
\text { Rare: pristine crystals and reshaped discoid } \\
\text { flakes } \\
\text { Roundness subangular }\end{array}$ & $\begin{array}{l}\text { V. Saarinen (several unpublished reports in } \\
\text { GSF archives) } \\
\text { Kauranne (1990) } \\
\text { Kinnunen et al. (1997) }\end{array}$ \\
\hline Surface textures & $\begin{array}{l}\text { Primary markings: primary cavities } \\
\text { Secondary markings: groove and shaving }\end{array}$ & This study \\
\hline
\end{tabular}
scratches, rimmed pits, rippled grooves, impact pits, microgold crystals, varnish Anthropogenic markings: burnished projections, lines, toolmarks

Color (Munsell Yellowish orange (10 YR 7/6)

code)

Density

Average chemical composition

Inclusions

Age estimate

Transport mechanisms

\section{Common: 11-14}

Rare: up to 17 , down to 5-9 (mixed nuggets)

Au 90-94 wt.\%, Ag 5-8\%, Bi 1\%, Cu 0.1\%. Au-rich (over $99 \%$ ) outer rim commonly present

Common: quartz, epidote, chlorites, pyrite, native bismuth, bismuth tellurides, imprints of carbonate (?) crystals

Rare: pyrrhotite, chalcopyrite, arsenopyrite, hematite, magnetite, goethite, altered micas, limonitic material, galena, Fe-Ni-Co sulphoarsenides, molybdenite

Isotopic composition of trace lead in gold: $1935 \pm 100 \mathrm{Ma}(?)$

Concentration during preglacial weathering

Glacial transport and redeposition Enrichment in glaciofluvial and fluvial processes
Kinnunen et al. (1997)

M. Terho in Kinnunen et al. (1995, 1996,

1997) and unpublished measurements

Sundell (1936)

Wilska (1952)

Saarnisto and Tamminen (1987)

B. Johanson in Kinnunen et al. (1995, 1996)

Ervamaa (1975)

Saarnisto and Tamminen (1987)

Kinnunen (1991, 1992)

M. Vaasjoki in Saarnisto et al. (1991)

Saarnisto and Tamminen (1987) 
primary and secondary surface markings. This feature and the morphology of the primary cavities and the chemical composition of the inner parts of the nuggets (Saarnisto et al. 1991, Kinnunen et al. 1995, 1996, 1997) show that the placer gold from Finnish Lapland was originally lithogenic, rather than supergene, bedrock gold. The similarities of surface texture types in different localities and on nuggets of different sizes suggests uniform transport mechanisms for the nuggets.

The identification and analysis of the surface textures of gold nuggets have specific practical applications. They can be used to discriminate between natural nuggets and fakes (Kinnunen and Vilpas 1994) and can also be used for fingerprinting valuable museum-quality nuggets (Kinnunen et al. 1995, 1996, 1997). They can be used in mineralogical reconnaissance as a guide for gold transport and sometimes for provenance characteristics. However, the proportion of anthropogenic markings increase with prolonged human handling and have obscured the secondary markings in particular. For this reason recently recovered gold nuggets should be chosen for studies relating to geological interpretations.

ACKNOWLEDGEMENTS: The author is very grateful to the gold prospectors and jewellers Aarne Alhonen, Kari Merenluoto, Raimo Kanamäki and Pekka Väätäinen, and to the Bank of Finland for loaning precious gold nuggets for nondestructive study. Lively discussions with Professor Matti Saarnisto, Pentti Karhunen, Dr. Heikki Hirvas, Dr. Peter Sorjonen-Ward, Mauri Terho, Risto Puranen, gold historian Seppo J. Partanen and several other gold enthusiasts in Finland have been most inspiring. The manuscript was reviewed by Risto Puranen, Dr. Ron DiLabio, Professor Matti Saarnisto, Mikko Tontti and an anonymous referee. I thank them all warmly. 


\section{REFERENCES}

Anthony, J.W., Bideaux, R.A., Bladh, K.W. and Nichols, M.C. (1990) Handbook of Mineralogy, Volume 1, Elements, Sulfides, Sulfosalts. Mineral Data Publishing, Tucson, 588 p.

Antweiler, J.C. and Campbell, W.L. (1977) Application of gold compositional analyses to mineral exploration in the United States. Journal of Geochemical Exploration 8, 17-29.

Bowie, S.H.U. and Simpson, P.R. (1977) Microscopy: reflected light. Pp. 109-165 in Physical Methods in Determinative Mineralogy, ed. by J. Zussman, Academic Press, London.

Craig, J.R. (1990) Ore textures and paragenetic studies - some modern case histories and sources of comparative data. Pp. 263-317 in Advanced Microscopic Studies of Ore Minerals, Short Course Handbook, Volume 17, Mineralogical Society of Canada, Ottawa.

Culver, S.J., Bull, P.A., Campbell, S., Shakesby, R.A. and Whalley, W.B. (1983) Environmental discrimination based on quartz grain surface textures: a statistical investigation. Sedimentology 30, 129136.

DiLabio, R.N.W. (1991) Classification and interpretation of the shapes and surface textures of gold grains from till. In: International Symposium on Alluvial Gold Placers, eds. G. Hérail and M. Fornari, La Paz, Orstom, p. 297-313.

Dowling, K. and Morrison, G. (1989) Application of quartz textures to the classification of gold deposits using North Queensland examples. Pp. 342-355 in The Geology of Gold Deposits, eds. R.R. Keays and W.R.H. Ramsay, Economic Geology Monograph 6.

Ervamaa, P. (1975) Selostus Tankavaaran ja Morgamin alueen sekahipuista tehdystä alustavasta tutkimuksesta. Geological Survey of Finland, unpublished report, M17/Sdk//r/52/2. $5 \mathrm{p}$.

Gale, S.J. and Hoare, P.G. (1991) Quaternary Sediments. Petrographic Methods for the Study of Unlithified Rocks. Belhaven Press, New York, 323 p.

Groen, J.C., Craig, J.R. and Rimstidt, J.D. (1990) Gold-rich rim formation on electrum grains in placers. Canadian Mineralogist 28, 207-228.

Hallbauer, D.K. and Utter, T. (1977) Geochemical and morphological characteristics of gold particles from recent river deposits and the fossil placers of the Witwatersrand. Mineralium Deposita 12, 293-306.
Herail, G. (1991) Evolution of the morhology and composition of gold grains from primary sources to supergene environment: general characteristics and application to the knowledge of Bolivian placers. In: International Symposium on Alluvial Gold Placers. La Paz, Bolivia, June 3-5, 1991, abstracts. La Paz: ORSTOM, p. 71-73.

Hertzberg, R.W. (1976) Deformation and Fracture Mechanics of Engineering Materials. Wiley, New York, $605 \mathrm{p}$.

Hirvas, H. (1991) Pleistocene stratigraphy of Finnish Lapland. Geological Survey of Finland, Bulletin $354,123 \mathrm{p}$.

Huhta, P. (1993) The Use of heavy mineral concentrates from till in gold exploration in the late Archean Hattu schist belt, Ilomantsi, eastern Finland. Geological Survey of Finland, Special Paper 17, 363-372.

Kauranne, L.K. (1990) Kulta Suomessa. Kultaseppien Lehti 3/1990, 10-13.

Kinnunen, K.A. (1991) Lemmenjoen alueen irtokullan alkuperäiskivilajien määritys sekahippujen petrografian perusteella. Unpublished report of investigation, Geological Survey of Finland M16/3812/91/1, $31 \mathrm{p}$.

Kinnunen, K.A. (1992) Laattatektoninen malmimalli voi selittää Lapin irtokultaesiintymien synnyn. Summary: Plate-tectonic model proposed for the evolution of placer gold in Finnish Lapland. Geologi 44 (7), 115-123.

Kinnunen, K.A. (1995a) New methods for photography through the microscope: application to gem materials. Geological Survey of Finland, Current Research 1993-1994, ed. S. Autio, Special Paper 20, 185-187.

Kinnunen, K.A. (1995b) Digitaalinen valokuvaus: uusi hyötykäyttö geologin PC-tietokoneelle. Geologi 47 (8), 114-119.

Kinnunen, K.A. and Vilpas, L. (1994) Kultahippujäljitelmien erottaminen Lapin hippukullasta. Summary: Discrimination of faked nuggets from the natural gold nuggets of Finnish Lapland. Geologi 46 (9-10), 119-123.

Kinnunen, K.A., Johanson, B., Terho, M. and Puranen, R. (1995) Aleksin kultahipun (385 g) laboratoriotutkimuksista. Summary: Aleksi gold nugget (385 g) - laboratory studies. Geologi 47 (3), 3539.

Kinnunen, K.A., Johanson, B., Terho, M. and Puranen, R. (1996) Lemmenjoen alueen Puskuojalta elokuussa 1995 löytyneen Iivari-kultahipun $(126,95 \mathrm{~g})$ morfologia ja pintarakenne, kemiallinen 
ja mineraloginen koostumus sekä petrofysikaaliset ominaisuudet. Geological Survey of Finland, unpublished report, M19/3812/96/1, 18 p. and one map.

Kinnunen, K.A., Johanson, B., Terho, M. and Puranen, R. (1997) Nondestructive analysis of morphology, chemical composition and physical properties of large gold nuggets from Finnish Lapland. Geological Survey of Finland, Current Research 1995-1996, ed. S. Autio, Special Paper (in press).

Knight, J. (1992) The use of the characteristics of native gold as an exploration tool: an overview with emphasis on Soviet contribution. Current Research, Part D; Geological Survey of Canada, Paper 92-1D, 67-72.

Krinsley, D.H. and Doornkamp, J.C. (1973) Atlas of quartz sand surface textures. Cambridge, University Press, $91 \mathrm{p}$.

Lawrance, L.M. and Griffin, B.J. (1994) Crystal features of supergene gold at Hannan South, Western Australia. Mineralium Deposita 29, 391-398.

Leake, R.C., Bland, D.J. and Cooper, C. (1993) Source characterization of alluvial gold from mineral inclusions and internal compositional variation. Trans. Instn Min. Metall. (Sect. B: Appl. earth sci.) 102, B65-B81.

Loen, J.S. (1995) Use of placer gold characteristics to locate bedrock gold mineralization. Explor. Mining. Geol. 4, 335-339.

Mahaney, W.C. (1991) Microtextures on quartz and gold grains transported by glaciers. In: International Symposium on Alluvial Gold Placers, eds. G. Herail and M. Fornari, La Paz: ORSTOM, p. 315-323.

Mahaney, W.C. (1995) Pleistocene and Holocene glacier thickness, transport histories and dynamics inferred from SEM microtextures on quartz particles. Boreas 24, 293-304.

McCall, J.L. and French, P.M. (1977) Metallography in Failure Analysis. Plenum Press, New York, 301 p.

Mercer, M.E. (1992) Methods for determining the gold content of jewellery metals. Gems \& Gemology 28 (4), 222-233.

Nikkarinen, M. (1991) Size, form and composition of gold grains in glacial drift in Ilomantsi, eastern Finland. Journal of Geochemical Exploration 39, 295-302.
Petrovskaya, N.V. (1971) Growth and subsequent changes in native gold crystals. Mineralogical Society of Japan, Special Paper 1, 116-123.

Prest, V.K. (1983) Canada's heritage of glacial features. Geological Survey of Canada, Miscellaneous Report 28, 119 p.

Puustinen, K. (1991) Gold deposits of Finland. Journal of Geochemical Exploration 39, 255-272.

Rabinowicz, E. (1968) Polishing. Scientific American 218 (6), 91-99.

Rahmani, R.A. (1973) Grain surface etching features of some heavy minerals. Journal of Sedimentary Petrology 43 (3), 882-888.

Saarnisto, M. and Tamminen, E. (1987) Placer gold in Finnish Lapland. Geological Survey of Finland, Special Paper 3, 181-194.

Saarnisto, M., Tamminen, E. and Vaasjoki, M. (1991) Gold in bedrock and glacial deposits in the Ivalojoki area, Finnish Lapland. Journal of Geochemical Exploration 39, 303-322.

Sarkar, A.D. (1976) Wear of Metals. Pergamon Press, Oxford, $164 \mathrm{p}$.

Sundell, I.G. (1936) Fineness and composition of alluvial gold from the Ivalojoki, Finnish Lapland. Bull. Comm. Geol. Finlande 115, 155-160.

Sustavov, O.A. (1985) Gold content as a function of grain size of vein quartz. Doklady, Earth Science Sections 275 (1-6), 83-85.

Tarbayev, M.B. (1991) Typomorphism of gold crystals from quartz reefs. Pp. 353-357 in Brazil Gold'91, ed. E.A. Ladeira, Balkema, Rotterdam.

Tolansky, S. (1960) Surface Microtopography. Longmans, London, 296.

Ward, P., Härkönen, I., Nurmi, P.A. and Pankka, H.S. (1989) Structural studies in the Lapland greenstone belt, northern Finland and their application to gold mineralization. Current Research 1988, Geological Survey of Finland, Special Paper 10, 71-77.

Wilska, S. (1952) Trace elements in gold washed in Finnish Lapland. Suomen Kemistilehti B 25 (12), 75-79.

Yeend, W. (1975) Experimental abrasion of detrital gold. Journal of Research U.S. Geological Survey 3 (2), 203-212.

Yeend, W. (1991) Experimental abrasion of detrital gold in a tumbler. U.S. Geological Survey Bulletin 2041, 86-92. 